Egyptian Poultry Science Journal

http://www.epsaegypt.com

ISSN: 1110-5623 (Print) - 2090-0570 (Online)

\title{
APPLICATION OF PREBIOTICS AS FEED ADDITIVES IN
} POULTRY NUTRITION-A REVIEW

\author{
M.M.N. Ahmed; Z.S.H. Ismail and A.A.A. Abdel-Wareth
}

Dep. of Anim.and Poult. Prod., Fac. of Agric., South Valley Uni., 83523 Qena, Egypt

*Correspondence to: Ahmed Abdel-Wareth, E-mail: a.wareth@agr.svu.edu.eg

Received: 10/02/2018

Accepted: 26/02/2018

\begin{abstract}
Since the EU banned antibiotic growth promoters (AGPs) in poultry nutrition, many researches has been conducted to explore the use of possible effective substitutes. Prebiotic products are incorporated in poultry feed to replace AGPs in order to stimulate or promote the effective use of feed nutrients which may subsequently result in more higher production rates and improved feed efficiency and induce the growth and activity of beneficial microorganism. Moreover, prebiotic may improve digestion and stimulate the immune system in poultry. Consequently, several researches were performed to confirm their beneficial qualities. Productive performance that were dominantly observed and analyzed are feed intake, body weight gain and feed conversion ratio. Most of the trials showed slight positive effects, however significant results were rare. Since there are almost unlimited possibilities concerning dosage and products of prebiotic there is still more research needed. Therefore, it is necessary to define and declare the composition of prebiotic used in experiments. Generally, it can be stated that prebiotic have the potential to be considered as an alternative to AGPs in poultry nutrition. Nevertheless, there is still further research under more standardized condition needed to evaluate the right dosage and the exact mechanism of actions.
\end{abstract}

Keyword: Prebiotic -Productive - Nutrient digestibility - Microbial populations-Poultry 


\section{INTRODUCTION}

Many research have been conducted to define and explore the importance of using prebiotics. Various types of oligosaccharides, including inulin, fructooligosaccharides (FOS), galactooligosaccharides (GOS), soyaoligosaccharides (SOS), xylooligosaccharides (XOS), pyrodextrins, isomalto-oligosaccharides (IMO), lactulose and mannanoligosaccharide (MOS) are commonly considered as prebiotics (Alloui et al., 2013). Prebiotics are a general term to refer to chemicals that induce the growth or activity of microorganisms (e.g., bacteria and fungi) that contribute to the well-being of their host (Schloss, 2014). The most common example is in the gastrointestinal tract, where prebiotics can alter the composition of organisms in the gut microbiome and it is defined as "a nondigestible food ingredient that beneficially affects the host by selectively stimulating the growth and activity of one or a limited number of bacteria in the colon (Roberfroid, 2007). Roberfroid (2007) stated that only two particular prebiotics then fully met this definition: trans-galactooligosaccharide and inulin Moreover, Coxam (2007) reported that prebiotic should increase the number or activity of bifidobacteria and lactic acid bacteria, the importance of the bifidobacteria.

The lactic acid bacteria may have several beneficial effects on the host, especially in terms of improving digestion including enhancing mineral absorption, and the effectiveness and intrinsic strength of the immune system (Seifert and Watzl, 2007). The immediate addition of substantial quantities of prebiotics to the diet may result in an increase in fermentation, leading to increased gas production, bloating or bowel movement (Marteau and Seksi, 2004). Until bacterial flora are gradually established to rehabilitate or restore intestinal bacteria, nutrient absorption may be impaired and colonic transit time temporarily increased with an immediate addition of higher prebiotic intake (Marteau and Seksik, 2004).

In some studies the ability of prebiotic to be used as alternative feed additive has already been proven and thus started to play a decisive role in nutrition of poultry. The benefits of MOS are based on specific properties, including modification of the intestinal micro-flora, reduction in turnover rate of the intestinal mucosa, and modulation of the immune system in the intestinal lumen, these properties have the potential to enhance growth rate, feed efficiency, and livability in poultry species (Parks et al., 2001). Nevertheless, the uses of prebiotics in diets for poultry have been shown improvement in bird's immunity and increasing performance. In some studies the ability of prebiotic to be used as alternative growth promoters has already been proven and thus started to play a decisive role in nutrition of poultry. Anyhow, only limited research is available, which handicaps full comprehension of physiological responses. Therefore, the purpose of this study is to give an overview on the definition of prebiotics as feed additives ingredients, its composition and mode of action, as well as on the use of these prebiotic ingredients in poultry diets with particular attention on the effects of prebiotics on performance characteristics, nutrient digestibility, carcass criteria, and intestinal microflora. 


\section{Prebiotic - Productive - Nutrient digestibility - Microbial populations-Poultry}

\section{Prebiotic components mode of action}

Prebiotics defined as a nondigestible food that is used as an energy source by beneficial bacteria found naturally in the body's intestines much of the interest in prebiotics is focused on nondigestible fibers found in plants, mainly oligosaccharides such as inulin type fructooligosaccharides (FOS), mannanoligosaccharide (MOS) and transgalactooligosaccharides

(Roberfroid, 2007). Prebiotics may have beneficial effects on the animal's physiology by selectively stimulating beneficial microbiota in the digestion system. This may have beneficial effects in reducing the incidence of enteric pathogens. Competitive exclusion of pathogens by increasing numbers of microbiota that are associated with a healthy host can produce a variety of bacteriocins that have a detrimental effect on the pathogen by promotion of macrophages, stimulation of antibody production, and antitumour effects (Vamanu and Vamanu, 2010). Prebiotics may be able to have directly effect on the pathogen or on the host in a microbiotaindependent manner. Another mode of action is ability and adhering competition of represents colonization in the intestinal mucous membranes to prevent adhesion and invasion of pathogens and, which is a key performance parameter, inhibition of their colonization and replacement of already adhered ones (Patterson and Burkholder, 2003).

There is evidence that the principal mechanisms of prebiotics is immunomodulation, that includes selective growth of lactic acid-producing bacteria, resulting in an increasing in the concentration of short chain fatty acids (SCFA) like propionate, acetate, and especially butyrate which is the preferred energy source of colon oocytes and stimulates gut integrity (Alloui et al., 2013). High fermentation activity and high concentration of the SCFA is correlated with a lower $\mathrm{pH}$, which is associated with a suppression of pathogens and increased solubility of certain nutrients (Józefiak et al., 2004). Fermentation products such as SCFA increase after prebiotic supplementation as a result of oligosaccharide fermentation by resident microbiota. Short chain fatty acids (SCFA) production is an important physiological process of colonic microorganisms and may be useful in improving gastrointestinal health by reducing the occurrence of diarrhoea through modulating the microbiota (Macfarlane et al., 2008). This phenomenon may inhibit some pathogenic bacteria and reduce colonization of some species like Salmonella and Campylobacter (Charalampopolus and Rastall, 2009). Supplementary dietary MOS improves animal resistance to enteric disease and promotes growth by prevent colonization of enteric pathogens, inhibiting bacterial adhesion to gut lining, improves the brush border mucin barrier, changes microflora fermentation to favour nutrient availability for the host, improves immunity, enhances the unity of the gut lining and brings down enterocyte turnover rate (Ferket, 2003).

\section{Effects of prebiotics on productive performance}

Several studies have been conducted to explore the effect of prebiotic on poultry performance (Table 1). Toghyani et al. (2011) found that adding $1 \mathrm{mg} / \mathrm{kg}$ mannanoligosaccharide (MOS) in broiler chicks diets results in significantly $(\mathrm{P}<0.05)$ higher feed intake and body weight over 14-28 d and overall period 
M.M.N. Ahmed et al .

compared to control chicks. Feed efficiency and productive performance of birds receiving the supplementation of prebiotic improved over different periods in comparison to control birds (Spring et al., 2000). The feed conversion ratio describes the relation of feed intake and body weight gain. More precisely, it is the animals overall efficiency in converting feed mass into body mass over a specific period of time. Konca et al. (2009) found that $1 \mathrm{mg} / \mathrm{kg}$ mannan oligosaccharide increased feed intake and feed conversion ratio significantly $(\mathrm{P}<0.05)$ in turkey during 10 to 20 weeks of age. Also, Sohail et al. (2012) demonstrated that adding MOS to broiler chicks diet had gave higher $(\mathrm{P}<0.05)$ body gain, feed intake and better feed conversion ratio compared with the control group under heat stress. AbdelRaheem et al. (2011) reported that $2 \mathrm{~g} / \mathrm{kg}$ mannan-Oligosaccharide (MOS) in the starter diets and $0.5 \mathrm{~g} / \mathrm{kg}$ of the grower diets had increased feed intake and body weight as well as reduced mortility rate of broiler chickens. Abdel-Wareth, (2016) found that supplementation of symbiotic to laying hens diet improved feed intake and productive efficiency. Furthermore Murshed et al. (2015) found that used (Techno Mos) at $0.75 \mathrm{~g} / \mathrm{kg}$ in starter diet and $0.6 \mathrm{~g} / \mathrm{kg}$ in the finisher diet had improvements in body weight and body gain of broiler chickens. Also Wang and Zhou, (2007) reported that using of prebiotics (mannose oligosaccharides at $3000 \mathrm{mg} / \mathrm{kg}$ at age of 0 to 2 weeks and $2500 \mathrm{mg} / \mathrm{kg}$ at 3 to 7 weeks, significantly increased body weight gain, feed intake and improved feed efficiency than the non-supplemented group. Likewise, dietary supplementation of probiotics and prebiotics improved body weight gain and feed conversion ratio of broilers at 28 days of age (Yun et al., 2017). Awad et al. (2009) reported that a mixture of probiotics and prebiotics products had comparable potential to improve broiler performance as an avilamycin treatment. In addition, supplemental inulin at 10 $\mathrm{g} / \mathrm{kg}$ diet improved body weight gain and feed efficiency of female chickens (Yusrizal and Chen, 2003). Productive performance in broilers has been evaluated with addition of prebiotic. Body weight, feed intake and feed conversion ratio were reported to improve in the majority of studies (Zduńczyk et al., 2005; Yang et al., 2008; Baurhoo et al., 2007). In comparison with the control group, dietary supplementation with 100 $\mathrm{mg} / \mathrm{kg}$ of chito-oligosaccharide improved the growth of broilers during both the starter and grower periods as well as over the entire experimental period ( $\mathrm{Li}$ et al., 2007).

On the other hand many researchers found that supplementation of prebiotic did not affect productive performance (Midilli et al., 2008; Yalcınkaya et al., 2008). Also the dietary MOS supplementation did not affect $(\mathrm{P}>0.05)$ body weight and body gain (Waldroup et al., 2003; Yalcinkaya et al., 2008). Rehman et al. (2008) observed that inulin at $1 \mathrm{~g} / \mathrm{kg}$ diet had no effect on the final BW of broilers. Also, Alzueta et al. (2010) showed that the addition of inulin (from 5 to $20 \mathrm{~g} / \mathrm{kg}$ ) to a maize-soybean meal based diet did not improve the growth performance of broiler chickens. In harmony with these results, mortality was non-significant $(\mathrm{P}>0.05)$ by adding MOS at 21 days of age (Gao et al., 2008). Furthermore Murshed et al. (2015) found that used (Techno Mos) at $0.75 \mathrm{~g} / \mathrm{kg}$ in starter diet and $0.6 \mathrm{~g} / \mathrm{kg}$ in the finisher diet did not influenced feed intake of broiler chickens. 


\section{Prebiotic - Productive - Nutrient digestibility - Microbial populations-Poultry}

The variations in results of previous studies could be due to feed intake and body gain depend on several factors like genotype, housing, hygienic conditions, management, feeding system and diet attributes. Also this is due to the lack of standardization in varying parts of experimental research. Nevertheless it has to be kept in mind that there is still insufficient significant evidence on prebiotic as natural growth promoters on ducks.

\section{Effects of prebiotics on nutrients digestibility}

Beneficial effects of prebiotic on nutrient digestibility of poultry are reported only rarely (Table 2). Alzueta et al. (2010) showed that inulin supplementation improved the digestibility of protein and fat in a maize-soybean meal based diet, but had no effect on the performance of broiler chickens. Boilers fed prebioticsbased diets had improved dry matter digestibility compared with control group (Yun et al., 2017). The nutrient digestibility of dry matter was improved by feed additives of probiotics in broilers (Apata, 2008). Likewise, Mountzouris et al. (2010) found that supplementation of $108 \mathrm{CFU} / \mathrm{g}$ probiotics/kg increased dry matter digestibility in broilers. These results infer that dry matter digestibility was improved due to an increase in the beneficial microorganism, such as Lactobacillus. Moreover, the prebiotic induce changes in the intestinal mucosal structure (Rehman et al., 2007) and to improve gut health (Roberfroid, 2005). Compared with the birds in the control, the birds receiving $100 \mathrm{mg} / \mathrm{kg}$ of chitooligosaccharide had better nutrient digestibility of dry matter, crude protein, energy, calcium, and phosphorus (Liet al., 2007). Supplementation of chitooligosaccharide improved gut health and thus increased nutrient digestibility in broilers (Huang et al., 2005). Tuohy et al. (2003) reported that supplementation of oligosaccharide to broiler diet improved the nutrient digestibility as was due to an improvement in gut health. Wang et al. (2005) also reported that dietary supplementation of $125 \mathrm{mg} / \mathrm{kg}$ of chitooligosaccharide improved nutrient digestibility by improving gut health.

The beneficial effects of prebiotic on nutrient digestibility might be related to some of the effects attributable to prebiotics, particularly their ability to induce beneficial changes in the intestinal microflora and to improve gut health (Alzueta et al., 2010). Supplementation of prebiotic to broiler chickens enhances the intestinal mucosal structure, including increase in the length of villi (Rehman et al., 2007). On the other hand, Biggs et al. (2007) who reported that supplementation of inulin to broiler diets at $8 \mathrm{~g} / \mathrm{kg}$ diet depressed amino acid digestibility but that no deleterious effect was found at a lower concentration $(4 \mathrm{~g} / \mathrm{kg})$. Fructooligosaccharide supplementation at $20 \mathrm{~g} / \mathrm{kg}$ to male pigeon's diet had no significant effects on nutrient digestability (Janssens et al., 2004). Ratriyanto et al. (2009) reported that used supplementation of inulin at $2 \mathrm{~g} / \mathrm{kg}$ in piglet's diet, did not affect the ileal digestibilities of dry matter, crude protein, ether extract and crude fiber. These apparent contradictions in the effectiveness of prebiotic when fed to birds may be related to prebiotic source used, dosages, type of diet, animal characteristics, hygiene, husbandry conditions and environmental stress (Patterson and Burkholder, 2003). 
M.M.N. Ahmed et al .

Effects of prebiotics on carcass criteria Certain types of prebiotics have been used as feed additives to improve animal performance and enhance carcass criteria (Table 3, Owens and McCracken, 2007; Pelicano et al., 2004). Feeding prebiotic to broilers increased $(p<0.05)$ the relative weight of gizzard and proventriculus, spleen, bursa of fabricius, and the two ceca (Abdel-Hafeez et al., 2017). Furthermore Abdel-Raheem et al. (2011) reported that there is a significant increase $(\mathrm{p}<0.05)$ in the carcass weight and dressing \% as well as in the absolute weight of the immune organs (bursa and thymus), in prebiotic supplemented broilers group. These results were in harmony with those results of previous studies (Wang et al., 2003; Huang et al., 2007) However, Yang et al. (2007) reported that dietary MOS supplementation decreased intestine and liver weight in broilers. Mahmud et al. (2008) reported that addition of prebiotic (MOS) to birds diet had reduced abdominal fat percentage value compared to the birds fed the control diet. No clear mechanisms have been reported to be responsible for the reduction of lipid synthesis by prebiotics. It might in part be due to increasing beneficial bacteria such as Lactobacillus that increased the activity of acetyl-CoA carboxylase, which is the rate limiting enzyme in fatty acids synthesis (Abdel-Hafeez et al., 2017). On the other hand, Toghyani et al. (2011) found that carcass traits evaluated including liver, pancreas, gizzard, heart, small intestine and cecum weights, small intestine, and cecum lengths were not markedly affected by dietary supplementation of prebiotic treatments. Adding MOS on carcass had no significant effect on carcass and cut-part yields (breast, thigh, wing, liver, heart, gizzard, intestinal system or abdominal fat (Mahmud et al., 2008; Midilli et al., 2008; Konca et al., 2009). Supplementation of prebiotic had no significant effect on abdominal fat of broilers chickens (Waldroup et al., 2003; Bozkurt et al., 2005). Likewise, Wang and Zhou, (2007) observed that were no significant in carcass yield, internal organs and breast yield. Supplementation of prebiotic to broilers diets did not affect ( $p>0.05)$ the carcass yield, liver, heart, and small intestine (Abdel-Hafeez et al., 2017). Also, it was seen that the spleen weight did not show any significant effect between prebiotics (Awad et al., 2009). Midilli et al. (2008) who did not observe any significant impact of Mannanoligosaccharides on carcass yield. The weight of gizzard, liver and bursa of fabricius did not show any significant difference $(\mathrm{P}>0.05)$ by supplementation of prebiotic (Odefemi, 2016). As far as the literature denotes, the effect of prebiotics as feed additives on carcass traits and meat quality still has not been well studied.

\section{Effect of prebiotic on microbial populations}

It is generally known that the beneficial gut bacteria play an important role in host metabolism, nutrient digestion, growth performance and health of the host poultry. Prebiotics are current strategies with great potential to modify and manipulate the gut microbiota. Effects of prebiotics on microbial populations of previous studies are presented in Table 4. Geier et al. (2008) who reported that MOS at $5 \mathrm{~g} / \mathrm{kg}$ and FOS at $5 \mathrm{~g} / \mathrm{kg}$ supplementation in Cobb 500 birds resulted in significant increase in ileal Lactobacillus profile. Prebiotics have been reported to beneficially affect the microbiota, improve nutrient utilization 


\section{Prebiotic - Productive - Nutrient digestibility - Microbial populations-Poultry}

and enhance the immune system (Patterson and Burkholder, 2003; Biggs et al., 2007; Huang et al., 2007). A number of studies have demonstrated that dietary inclusion of MOS can increase intestinal numbers of beneficial bacteria such as lactobacilli and bifidobacteria, whilst decreasing E. coli (Baurhoo et al., 2007). Fernandez et al., 2002 demonstrated that MOS is effective in reducing Salmonella infection of birds. Baurhoo et al. (2007) found the addition of MOS significantly reduced E. coli counts in both litter and ceca samples in broilers.

Dietary MOS inhibits growth of intestinal pathogenic microorganisms through binding to cell walls of bacteria preventing the bacteria from attaching to intestinal epithelial cells (Spring et al., 2000). Choi et al. (1993) reported that FOS supplementation at the level of $0.22 \%$ increased bifidobacteria and lactobacilli and decreased C. perfringens and E. coli populations in the ileal content of broilers. Sims et al. (2004) showed that 6-wk-old turkeys in a MOS treatment group had significantly less $\mathrm{C}$. perfringens in their large intestines than did the control birds. Fructooligosaccharide may help to control or reduce the growth of harmful bacteria such as C. perfringens (Hofacre et al., 2005). Baurhoo et al. (2007, 2009) reported an increase of lactobacilli and bifidobacteria in the ceca of broilers due to dietary MOS. While Spring et al. (2000) noted a decrease of Salmonella in the ceca of broilers, but no difference in lactobacilli, coliforms, enterococci, and anaerobic bacteria. However, AbdelRaheem et al. (2012) reported that using MOS at $2 \mathrm{~g} / \mathrm{kg}$ of the starter diets and 0.5 $\mathrm{g} / \mathrm{kg}$ of the grower diets in chicks, failed to elicit any significant $(\mathrm{P}>0.05)$ effect on the total lactobacilli and $\mathrm{E}$ coli colony counts at day 21 in the different parts of the small intestine (duodenum, jejunum, ileum and cecum). Yang et al. (2007) have not seen any significant difference with supplementation of MOS in ceca microbiology populations. Bonos et al. (2010) used MOS by $1 \mathrm{~g} / \mathrm{kg}$ and $2 \mathrm{~g} / \mathrm{kg}$ in two hundred twenty-five 1-day old Japanese quail diet, they reported that on day 21 , there was a tendency $(\mathrm{P} \leq 0.100)$ for group MOS $1 \mathrm{~g}$ to have a higher total aerobic bacteria count compared to group control, but there was no significant difference for the other bacterial populations. Ghosh et al. (2007) found no significant difference on coliforms or E. coli counts in the small intestine of quail, but a decrease of Clostridium perfringens. Sims et al. (2004) found no significant difference on lactobacilli, coliforms, and E. coli in turkeys fed MOS. Ratriyanto et al. (2009) used inulin alone by $0.2 \%$ in piglets diet, they reported that dietary supplementation with inulin to a piglet's diet did not affect $(\mathrm{P}>0.05)$ the concentration of various microbial metabolites both at the ileal and faecal level. It could be stated that adding prebiotic to poultry diets can improve health status of bird's gastrointestinal tract by reducing the harmful bacteria and increasing the beneficial bacteria.

\section{CONCLUSION}

Generally, it can be recommended that prebiotic components have the potential to be considered as an alternative to in feed-antibiotic and improving productive performance and health status of poultry. Nevertheless, there is still further research under standardized conditions needed to evaluate the exact mechanism of action and to determine the optimal dietary inclusion level in order to optimize growth performance, nutrient digestibility and maintain healthy birds. 
M.M.N. Ahmed et al.

Table (1): Effects of prebiotics on productive performance

\begin{tabular}{|c|c|c|c|c|c|}
\hline $\begin{array}{l}\text { Source of } \\
\text { product }\end{array}$ & $\begin{array}{l}\text { Crud } \\
\text { protein }\end{array}$ & $\begin{array}{l}\text { Crude } \\
\text { Fibre } \\
\end{array}$ & $\begin{array}{l}\text { Ether } \\
\text { Extract }\end{array}$ & \begin{tabular}{|l|} 
Dry \\
Matter
\end{tabular} & Reference \\
\hline inulin & NS & NS & NS & NS & Ratriyanto et al., 2009 \\
\hline inulin & NS & - & - & - & Biggs et al., 2007 \\
\hline $\begin{array}{l}\text { Fructo- } \\
\text { oligosaccharide }\end{array}$ & NS & NS & NS & NS & Janssens et al., 2004 \\
\hline $\begin{array}{l}\text { chito- } \\
\text { oligosaccharide }\end{array}$ & Sig* & Sig* & Sig* & Sig* & Wang et al., 2005 \\
\hline $\begin{array}{l}\text { chito- } \\
\text { oligosaccharide }\end{array}$ & Sig* & Sig* & Sig* & Sig* & Li et al., 2007 \\
\hline
\end{tabular}

Table (2): Effects of prebiotics on nutrients digestibility

\begin{tabular}{|c|c|c|c|c|c|}
\hline $\begin{array}{l}\text { Source of } \\
\text { product }\end{array}$ & $\begin{array}{l}\text { Feed } \\
\text { intake }\end{array}$ & BW gain & FCR & Mortality & Reference \\
\hline MOS & $\operatorname{sig} *$ & $\operatorname{sig}^{*}$ & $\operatorname{sig} *$ & NS & Toghyani et al., 2011 \\
\hline MOS & $\operatorname{sig} *$ & NS & $\operatorname{sig}^{*}$ & - & Konca et al., 2009 \\
\hline $\begin{array}{l}\text { Techno } \\
\text { Mos }\end{array}$ & NS & $\operatorname{sig}^{*}$ & NS & - & Murshed et al, 2015 \\
\hline MOS & $\operatorname{sig}^{*}$ & $\operatorname{sig}^{*}$ & $\operatorname{sig}^{*}$ & NS & Sohail et al., 2012 \\
\hline MOS & $\operatorname{sig}^{*}$ & $\operatorname{sig}^{*}$ & $\operatorname{sig} *$ & - & Wang and Zhou, 2011 \\
\hline MOS & sig* & $\operatorname{sig}^{*}$ & sig* & NS & $\begin{array}{l}\text { Abdel-Raheem et al., } \\
2011\end{array}$ \\
\hline
\end{tabular}


Table (3):Effects of prebiotics on carcass criteria

\begin{tabular}{|l|c|c|c|c|c|c|c|c|c|}
\hline $\begin{array}{l}\text { Source of } \\
\text { product }\end{array}$ & $\begin{array}{l}\text { Live body } \\
\text { weight }\end{array}$ & Carcass & liver & heart & gizzard & Intestine & bursa & cecum & Reference \\
\hline MOS & - & NS & NS & NS & NS & NS & - & NS & Toghyani et al.,2011 \\
MOS & - & NS & NS & NS & NS & NS & - & NS & Konca et al., 2009 \\
MOS & - & NS & NS & NS & NS & NS & NS & NS & Midilli et al., 2008 \\
MOS & NS & NS & NS & NS & NS & NS & NS & NS & Wang and Zhou,2011 \\
NuS & NS & Sig* & NS & NS & NS & - & - & - & Abdel-Raheem et al., \\
MOS & - & - & NS & - & NS & - & NS & - & Odefemi, 20116 \\
MOS & - & NS & NS & NS & NS & NS & NS & NS & Mahmud et al., 2008 \\
\hline
\end{tabular}


Table (4): Effect of prebiotic on microbial population

\begin{tabular}{|c|c|c|c|c|c|c|}
\hline $\begin{array}{l}\text { Source of } \\
\text { product }\end{array}$ & E. coli & lactobacilli & Salmonella & Bifidobacteria & $\begin{array}{l}\text { Clostridium } \\
\text { perfringens }\end{array}$ & Reference \\
\hline $\begin{array}{l}\text { MOS and } \\
\text {,FOS }\end{array}$ & - & Sig* & - & - & - & Geier et al., 2008 \\
\hline MOS & Sig* & Sig* & - & Sig* & - & Baurhoo et al., 2007 \\
\hline FOS & Sig* & Sig* & - & Sig* & Sig* & Choi et al., 1993 \\
\hline MOS & NS & NS & - & -- & Sig* & Sims et al., 2004 \\
\hline MOS & - & - & - & - & Sig* & Hofacre et al., 2005 \\
\hline MOS & - & Sig* & - & Sig* & - & Baurhoo et al., 2009 \\
\hline MOS & - & NS & Sig* & - & - & Spring et al., 2000 \\
\hline MOS & NS & NS & - & - & - & Abdel-Raheem et al., 2012 \\
\hline MOS & NS & - & - & - & Sig* & Ghosh et al.,2007 \\
\hline Inulin & NS & NS & NS & NS & NS & Ratriyanto et al., 2009 \\
\hline
\end{tabular}


Prebiotic - Productive - Nutrient digestibility - Microbial populations-Poultry

\section{REFERENCES}

Abdel-Hafeez, H.M.; Elham, S.E.S.; Samar, S.T.; Ibrahim, M.I.Y. and Asmaa, S.A.A. 2017. Effects of probiotic, prebiotic, and synbiotic with and without feed restriction on performance, hematological indices and carcass characteristics of broiler chickens. Asian-Australas J Anim Sci 30:672-682.

Abdel-Raheem, S.M. and Abd-Allah, S.M.S. 2011. The effect of single or combined dietary supplementation of mannan oligosacharide and probiotics on performance and slaughter characteristics of broilers. Int $\mathrm{J}$ Poult Sci 11: 854-862.

Abdel-Raheem, S.M.; Abd-Allah, S.M.S. and Hassanein, K.M.A. 2012. The effects of prebiotic, probiotic and synbiotic supplementation on intestinal microbial ecology and histomorphology of broiler chickens. Int J Agro Veter Med Sci 4:277-289.

Abdel-Wareth, A.A.A. 2016. Effect of dietary supplementation of thymol, synbiotic and their combination on performance, egg quality and serum metabolic profile of Hy-Line Brown hens. Br Poult Sci 57:114-122.

Alloui, M.N.; Szczurek, W. and Świątkiewicz, S. 2013. The usefulness of prebiotics and probiotics in modern poultry nutrition: a review. Ann. Anim. Sci 13:17-32.

Alzueta, C.; Rodri'guez, M.L.; Ortiz, L.T.; Reble, A. and Trevino, J. 2010. Effects of inulin on growth performance, nutrient digestibility and metabolisable energy in broiler chickens. Br Poult Sci 393-398

Apata, D.F. 2008. Growth performance, nutrient digestibility and immune response of broiler chicks fed diets supplemented with a culture of
Lactobacillus bulgaricus. J Sci Food Agri 88:1253-1258.

Awad, W.A.; Ghareeb, K.; bdelRaheem, S. and Bohm, J. 2009. Effects of dietary inclusion of probiotic and synbiotic on growth performance, organ weights, and intestinal histomorphology of broiler chickens. Poult. Sci 88:49- 55.

Baurhoo, B.; Phillip, L. and RuizFeria, C.A. 2007. Effects ofpurified lignin and mannan oligosaccharides on intestinalintegrity and microbial populations in the ceca and litterof broiler chickens. Poult Sci 86, 10701078.

Baurhoo, B.; Ferket, P.R. and Zhao, X. 2009. Effects of diets containing different concentrations of mannanoligosaccharide or antibiotics on growth performance, intestinal development, cecal and litter microbial populations and carcass parameters of broilers. Poult. Sci 88:2262-2272.

Baurhoo, B.; Goldflus, F. and Zhao, X. 2009. Purifiedcell wall of Saccharomyces cerevisiae increases protectionagainst intestinal pathogens in broiler chickens. Int $\mathbf{J}$ Poult.Sci 8:133-137.

Biggs, P.; Parsons, C.M. and Fahey, G.C. 2007. The effects of several oligosaccharides on growth performance, nutrient digestibilities and cecal microbial populations in youngchicks. Poult Sci 86, 2327-2336.

Bonos, E.; Christaki, E.; Abrahim, A.; Soultos, N. and Paneri, P.F. 2010. Effect of dietary supplementation of mannan oligosaccharides on hydrogen ion concentration of the digestive tract and microbial populations of the ceca of Japanese quail (Coturnix japonica). Turkish J Veter Anim Sci 35: 263269. 
M.M.N. Ahmed et al .

Bozkurt, M.; Kucukyilmaz, K.; Catli, A.U. and Cinar, M. 2005. Growth performance and carcass yield of broiler chickens given antibiotic, mannan oligosaccharide and dextran oligosaccharide supplemented diets. Nutritional Biotechnology in the Feed and Food Industries pp:69

Charalampopolus, D. and Rastall, R.A. 2005. Prebiotics and probiotics science and technology. Springer Verlag, New York 1: p. 516.

Choi, K.H.; Um, J.S. and Paik, I.K. 1993. Effect of supplementaryfructooligosaccharides and oxytetracycline on the performanceand intestinal microflora of broiler chickens. Kor J Anim Nutr Feed 17:118-127.

Coxam, V. 2007. Current data with inulin-type fructans and calcium, targeting bone health in adults". J Nutr 137:2527S-2533S.

Ferket, P.R. 2003. Controlling gut health without the use of antibiotics. Proc. Carolina Poultry Nutrition Conference 57-68.

Fernandez, F.; Hinton, M. and Gils, B.V. 2002. Dietary mannanoligosaccharides and theireffect on chicken caecal microflora in relation to Salmonella enteritidis colonization.Avian Pathology 31:4958.

Gao, J.; Zhang, H.J.; Yu, S.H.; Wu, S.G.; Yoon, I.; Quigley, J.; Gao, Y.P. and Qi, G.H. 2008. Effects of yeast culture in broiler diets on performance and immunomodulatory functions. Poult. Sci 87:1377-1384.

Geier, M.S.; Torok, V.A.; Allison, G.E.; Ophel-Keller, K. and Hughes, R.J. 2008. Indigestible carbohydrates alter the intestinal microbiota but do not influence the performance of broiler chickens. J Appl Microbiol 106:1540-1548.

Ghosh, H.K.; Halder, G.; Samanta, G.; Paul, S.K. and Pyne, S.K. 2007. Effect of dietary supplementation of organic acid and mannanoligosaccharide on the performance and gut health of Japanesequail (Coturnix coturnix japonica). Asian J. Poult. Sci 1:1-7.

Hofacre, C.L.; Mathis, G.F. and Quiroz, M.A. 2005.Natural alternativesto prevent necrotic enteritis. Int. Poult. Prod 13:7-9.

Huang, R.L.; Ding, Z.Y.; Yang, C.B.; Yen, Y.L.; Xie, M.Y.; Wu, G.Y.; Li, T.G.; Li, L.L.; Tang, Z.R.; Kang, P.; Hou, Z.P.; Ding, D.; Xiang, H.; Kong, X.F. and Guo, Y.M. 2007. Dietary oligochitosan supplementation enhances immune status of broilers. $\mathbf{J}$ Sci Food Agri 87:153-159.

Huang, R.L.; Yin, Y.L.; Wu, G.Y.; Zhang, T.J.; Li, L.L.; Li, M.X.; Tang, Z.R.; Zhang, J.; Wang, B.; He, J.H. and Nie, X.Z. 2005. Effect of dietary oligochitosan supplementation on ileal nutrient digestibility and performance in broilers. Poult. Sci 84:1383-1388.

Janssens, G.P.J.; Millet, S.; Immersee F.V.; De Buck, J. and Hesta, M. 2004. The Impact of Prebiotics and Salmonellosis on Apparent Nutrient Digestibility and Salmonella Typhimurium Var. Copenhagen Excretion in Adult Pigeons (Columba Livia Domestica). Poult Sci 83:18841890.

Józefiak, D.; Rutkowski, A. and Martin, S.A. 2004. Carbohydrate fermentation in the avian ceca: a review. Anim. Feed Sci Technol 113:1-15. 
Prebiotic - Productive - Nutrient digestibility - Microbial populations-Poultry

Konca, Y.; Kirkpinar, F. and Mert, S. 2009. Effects of mannanoligosaccharides and live yeast in diets on the carcass, cut yields, meat composition and colour of finishing turkeys. Asian-Austral J Anim Sci 4:550-556.

Li, X.J.; Piao, X.S.; Kim, S.W. ; Liu, P.; Wang, L.; Shen, Y.B.; Jung, S.C. and Lee, H.S. 2007. Effects of ChitoOligosaccharide Supplementation on Performance, Nutrient Digestibility, and Serum Composition in Broiler Chickens. Poultry Science 86:11071114

Macfarlane, G.T.; Steed, H. and Macfarlane, S. 2008. Bacterial metabolism and health-related effects of galacto-oligosaccharides and other prebiotics. J Appl Microbial 104:305344.

Mahmud, A.; Khattak, F.M.; Ali, Z. and Pasha, T. 2008. Effect of early feed restriction on broiler performance, meal feeding on performance, carcass characters and blood constituents of broiler chickens. J Anim Vet Adv 8:2069-2074

Marteau, P. and Seksik, P. 2004. Tolerance of probiotics and prebiotics. J Clin Gastroenterol 38:S67-69.

Midilli, M.; Alp, M.; Kocabagli, N.; Muglali, Ö.H.,; Turan, N.; Yilmaz, H. and Çakir, S. 2008. Effects of dietary probiotic and prebiotic supplementation on growth performance and serum $\mathrm{IgG}$ concentration of broilers. South Afr J Anim Sci 38:21-27.

Mountzouris, K.C.; Tsitrsikos, P.; Palamidi, I.; Arvaniti, A.; Mohnl, M.; Schatzmayr, G. and Fegeros, K. 2010. Effects of probiotic inclusion levels in broiler nutrition on growth performance, nutrient digestibility, plasma immunoglobulins and cecal microflora composition. Poult. Sci 89:58-67.

Murshed, M.A. and Abudabos, A.M. 2015. Effects of the dietary inclusion of a probiotic, a prebiotic or their combinations on the growth performance of broiler chickens. Brazilian J Poult Sci 15:99-104.

Odefemi, T.R. 2016. Performance response and carcass characteristics of broilers fed dietary antibiotics, probiotics and prebiotics. Europ J Agri Forest Res 4:27-36.

Owens, B. and McCracken, K.J. 2007. A comparison of the effects of different yeast products and antibiotic on broiler performance. Br Poult Sci 48:49-54.

Parks, C.W.; Grimes, J.L.; Ferket, P.R. and Fairchild, A.S. 2001. The effect of mannanoligosaccharides, bambermycins, and virginiamycin on performance of large white male market turkeys. Poult Sci 80:718-723

Patterson, J.A. and Burkholder, K.M. 2003. Application of prebiotics and probiotics in poultry production. Poult Sci 82:627-631.

Pelicano, E.R.L.; Souza, P.A.; Souza, H.B.A.; Leonel, F.R.; Zeola, N.M.B.L. and Boiago, M.M. 2004. Productive traits of broiler chickens fed diets containing different growth promoters. Brazilian J Poult. Sci 6:177-182.

Ratriyanto, A.; Mosenthin, R.; Jezierny, D.; Sauer, N. and Eklund, M. 2009. Betaine, organic acids and inulin do not affect ileal and total tract nutrient digestibility or microbial fermentation in piglets. J Anim Feed Sci 18:453-464.

Ratriyanto, A.; Mosenthin, R.; Jezierny, D. and Eklund, M. 2009. 
M.M.N. Ahmed et al .

Effect of graded levels of dietary betaine on ileal and total tract nutrient digestibilities and intestinal bacterial metabolites in piglets. Journal of Animal Physiology and Animal Nutrition 94:788-796.

Rehman, H.; Hellweg, P.; Taras, D. and Zentek, J. 2008. Effects of dietary inulin on the intestinal shortchain fatty acids and microbial ecology in broiler chickens as revealed by denaturing gradient gel electrophoresis. Poultry Science 87:783-789.

Rehman, H.; Rosenkranz, C.; Bolem, J. and Zentek, J. 2007. Dietary inulin affects the morphology but not the sodium dependent glucose and glutamine transport in the jejunum of broilers. Poult Sci 86:118-122.

Roberfroid, M.B. 2005. Introducing inulin-type fructosns. $\mathrm{Br} \quad \mathrm{J}$ Nutr 93:S13-S25.

Roberfroid, M.B. 2007. Prebiotics: The Concept Revisited. J Nutr 137 830S$7 \mathrm{~S}$.

Schloss, P.D. 2014. Microbiology: An integrated view of the skin microbiome. Nature 514:44-45.

Seifert, S. and Watzl, B. 2007. Inulin and oligofructose: review of experimental data on immune modulation. J Nutr 137:2563S-2567S.

Sims, M.D.; Dawson, K.A.; Newman, K.E.; Spring, P. and Hooge, D.M. 2004. Effects of dietary mannan oligosaccharide, bacitracinmethylene disalicylate, or both on the live performance andintestinal microbiology of turkeys. Poult. Sci 83:1148-1154.

Sohail, M.U.; Hume, M.E.; Byrd, J.A.; Nisbet, D.J.; Ijaz, A.; Sohail, A.; Shabbir, M.Z. and Rehman, H. 2012. Effect of supplementation of prebiotic mannan-oligosaccharides and probiotic mixture on growth performance of broilers subjected to chronic heat stress. Poult Sci 91, 2235-2240.

Spring, P.; Weng, C.; Dawson, K.A. and Newman, K.E. 2007. The effects of dietary mannoligosaccharide on caecal parameters and the samonellachallenged broiler chicks. Poult Sci 9:205-211.

Toghyani, M.; Toghyani, M. and Tabeidian, S.A. 2011. Effect of probiotic and prebiotic as antibiotic growth promotersubstitutions on productive and carcass traits of broiler chicks. International Conference on Food Engineering and Biotechnology 9:82-86.

Tuohy, K.M.; Probert, H.M.; Smejkal, C.W. and Gibson, G.R. 2003. Using probiotics and prebiotics to improve gut health.Therapeutic Focus 8:692700 .

Vamanu, E. and Vamanu, A. 2010. The influence of prebiotics on bacteriocin synthesis using the strain Lactobacillus paracasei CMGB16. Afr J Microbiol Res 4:534-537.

Waldroup, P.W.; Fritts, C.A. and Fenglan, Y. 2003. Utilization of BioMos® mannan oligosaccharide and Bioplex ${ }^{\circledR}$ copper in broiler diets. In $\mathbf{J}$ Poult Sci 2:44-52.

Wang, J. and Zhou, H. 2007. Comparison of the effects of Chinese herbs, probiotics and prebiotics with those of antibiotics in diets on the performance of meat ducks. J Anim Feed Sci 16:96-103.

Wang, X.W.; Lin, X.; Zhang, L.; Du, Y.G.; Bai, X.F. and Shu, S.G. 2005. Effect of oligo-chitosan on broiler performance,small intestine structure and muscle mineral element 
Prebiotic - Productive - Nutrient digestibility - Microbial populations-Poultry

concentration. J China Cereals Oils Assoc 20:83-88.

Wang, X.W.; Du, Y.G.; Bai, X.F. and Li, S.G. 2003. The effect of oligochitosan on broiler gut flora, microvilli density, immune function and growth performance. Acta Zoonutrim Sin 15:32-45.

Yalcinkaya, I.; Gungor, T.; M. Basalan,M.; and Erdem, E. 2008. Mannan oligosaccharides (MOS) from Saccharomyces cerevisiae in broilers: Effects on performance and blood biochemistry. Turk. J. Vet. Anim. Sci. 32:1-6.

Yang, Y.; Iji, P.A. and Choct, M. 2007. Effects of different dietary levels of mannanoligosaccharide on growth performance and gut development of broiler chickens. Asian-Aust J Anim Sci 20:1084-1091.

Yang, Y.; Iji, A.; Kocher, P.A.; Mikkelsen, L.L. and Choct, M. 2007. Effects of mannanoligosaccharide on growthperformance, the development of gut microflora, and gutfunction of broiler chickens raised on new litter. J Appl Poult Res 16:280-288.
Yang, Y.; Iji, P.A.; Kocher, A.; Thomson, E.; Mikkelsen, L.L. and Choct, M. 2008. Effects of mannanoligosaccharide in broiler chicken diets on growth performance, energy, energy utilization, nutrient digestibility and intestinal microflora. Br Poult Sci 49:186-194.

Yun, W.; Lee, D.H.; Choi, Y.I.; Kim, I.H. and Cho, J.H. 2017. Effects of supplementation of probiotics and prebiotics on growth performance, nutrient digestibility, organ weight, fecal microbiota, blood profile, and excreta noxious gas emissions in broilers. J Appl Poult Res 26:584-592.

Yusrizal, Y. and Chen, T.C. 2003. Effect of adding chicory fructans in feed on broiler growth performance, serum cholesterol and intestinal length. Int J Poult Sci 2:214-219

Zduńczyk, Z.; Stanczuk, J.; Juśkiewicz, J. and Jankowski, J. 2005. Indices of response of young turkeys to diets containing mannan oligosaccharide or inulin. Veterinar. Zootech. T 31:98-101. 


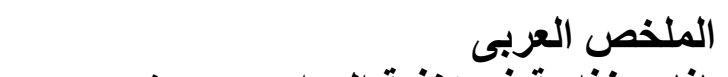 تطبيقات البريبيوتك كاضافات غذائية في تغذية الدواجن ـبحث مرجعي \\ ميرفت محمد ناصر احمد ، زينهم شيخون اسماعيل ، احمد ابوبكر عبدالمنعم عبدالوارث

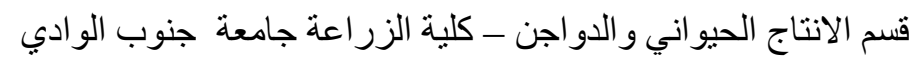

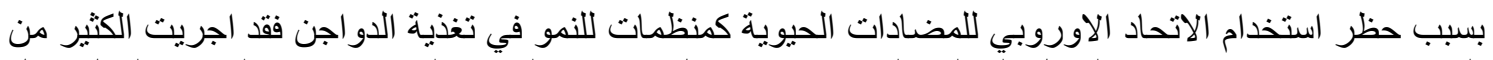

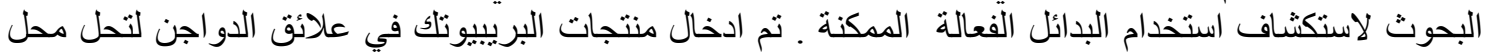

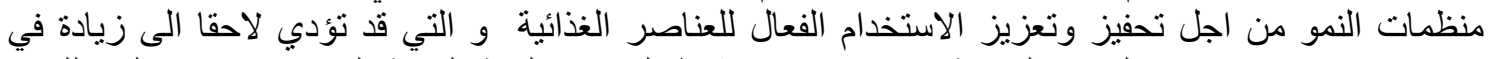

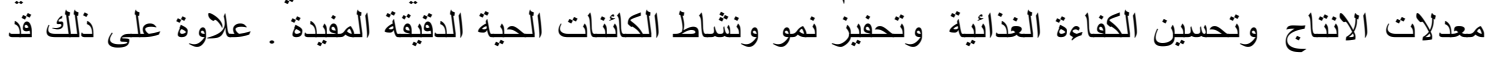

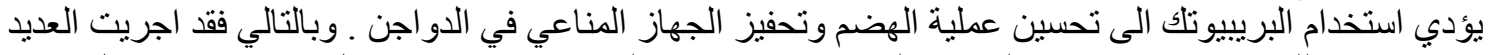

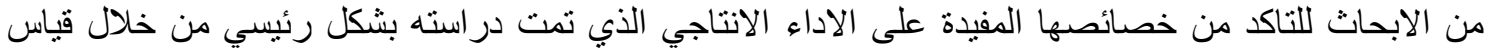

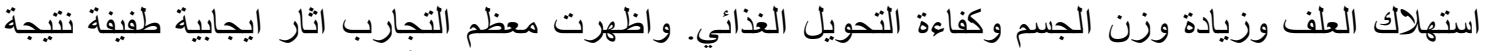

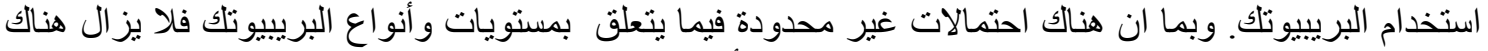

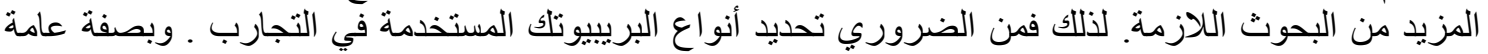

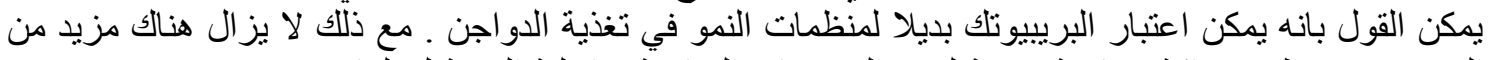

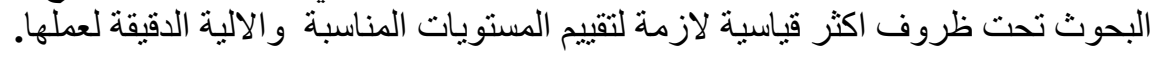

